\title{
Orhan Kemal'in Romanlarında Göç Merkezi Olarak Kentler ve Kültürel Araf
}

\section{Cities as Migration Centers and Cultural Limbo in Novels by Orhan Kemal}

\author{
Beyhan $\operatorname{Kanter}^{1}$ (1)
}

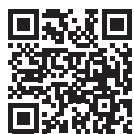

${ }^{1}$ Prof. Dr., Mardin Artuklu Üniversitesi, Türk Dili ve Edebiyatı Bölümü, Mardin, Türkiye

ORCID: B.K. 0000-0002-9848-022X

Sorumlu yazar/Corresponding author: Beyhan Kanter,

Mardin Artuklu Üniversitesi, Türk Dili ve Edebiyatı Bölümü, Mardin, Türkiye

E-mail: beyhankanter@gmail.com

Başvuru/Submitted: 17.04.2020

Revizyon Talebi/Revision Requested: 14.05.2020 Son Revizyon/Last Revision Received: 20.05.2020 Kabul/Accepted: 21.05 .2020

\section{Atıf/Citation:}

Kanter, B. (2020). Orhan Kemal'in romanlarında göç merkezi olarak kentler ve kültürel araf TUDED 60(1), 331-346.

https://doi.org/10.26650/TUDED2020-0018

\section{ÖZET}

Orhan Kemal, romanlarında, özellikle işçilerin, köylülerin, işsizlerin ve ezilen sınıfların sorunlarını ve hayata tutunabilme çabalarını iktisadi ve beşeri ilişkiler açısından ele alır. Yazar, işçi sınıfının sorunlarını anlattığı eserlerinde köyden kente göç olgusunu ise iktisadi sorunlar ve emeğin sömürüsünün yanı sıra kültürel araf bağlamında kurguya taşır. $\mathrm{Bu}$ çerçevede, sosyo-kültürel olarak arada kalmışlık, köyden kente göçün yol açtığı psikolojik ve sosyolojik olgular/travmalar üzerinden yansitılır. Büyük kentlere göç eden köylü bedenlerin dışlanma pratiklerine maruz kalmaları, "öteki bedenler", "gayrimedeni bedenler" olarak ayrıştırılmaları ve "kentli/modern bedenler" tarafindan etiketlenmeleri; Orhan Kemal'in romanlarındaki göç eksenli kültürel krizin sosyolojik yönünü oluşturmaktadır. Bununla birlikte kendi kültürlerine yabancılaşan, alışkanlıklarından, değerlerinden taviz veren/vermek zorunda kalan köylülerin, kentleri yurt edinme, kentsel pratikleri benimseme ve kentli bedenler tarafindan onaylanma mücadeleleri de Orhan Kemal romanlarındaki göç olgusunun psikolojik boyutunu oluşturmaktadır. Bu makalede Orhan Kemal'in Bereketli Topraklar Üzerinde ve Gurbet Kuşları romanlarında yer alan göç olgusunun sosyo-kültürel etkileri sosyolojik bakış açısıyla irdelenecektir. Söz konusu iki romandaki yoksul karakterlerin köyden kente göç ettiklerinde yaşadıkları kültürel karşılaşmalar ve kültürel çatışmalar, özellikle Pierre Bourdieu'nun "habitus" ve Erving Goffman'ın "damga" kavramları çerçevesinde açıklanacaktır. Göçün failleri ile göçe maruz kalan kentliler arasındaki gerilim ise mekânsal ötekileşme ve "davranış repertuvarları"na yansıyan farkl1lıklar özelinde değerlendirilecektir.

Anahtar Kelimeler: Orhan Kemal, göç, kültürel araf, yabancılaşma, habitus

\section{ABSTRACT}

In his novels, Orhan Kemal addresses problems and survival struggles of workers, peasants, the unemployed, and oppressed classes in terms of economic and human relations. In his novels in which he focuses on the problems of the working class, the author fictionalizes the concept of rural depopulation in the context of economic problems and labor exploitation as well as cultural limbo. In his novels, Bereketli Topraklar Üzerinde and Gurbet Kuşları, limbo as a sociocultural concept is reflected through psychological and sociological concepts/ traumas created by rural depopulation. The fact that peasants migrating to big cities suffer from discriminating practices, the fact that they are discriminated against "other people" and "uncivilized people," and that they are influenced by the urbanite constitute the sociological aspect of migration-based cultural limbo in Orhan Kemal's novels. In addition, the struggles of peasants who have become alienated from their own culture and compromise/have to compromise their habits and values in forming households in the city, adopting urban practices and being approved by the urbanite constitutes more of the psychological aspects of migration. In this article, the sociocultural effects of migration in Orhan Kemal's novels Bereketli Topraklar Üzerinde and Gurbet Kuşlart are examined through a sociological lens. Keywords: Orhan Kemal, migration, culturel limbo, alinetaion 


\section{EXTENDED ABSTRACT}

In his novels, Orhan Kemal addresses problems and survival struggles of workers, peasants, the unemployed, and oppressed classes in terms of economic and human relations. In his novels in which he focuses on the problems of the working class, the author fictionalizes the concept of rural depopulation in the context of economic problems and labor exploitation as well as cultural limbo. The concept of migration in Orhan Kemal's novels entails many expectations due to the economic opportunities offered by cities. Therefore, cities are in some way "a place of hope" that save the poor from the narrow boundaries set by the adverse circumstances in villages.

The first pieces of information on the city life of peasant characters in Orhan Kemal's novels are composed of a positive attitude towards the city and a negative attitude towards the urbanite in individuals migrating to the city for work. While the city that peasants migrate to is Adana in his novel titled Bereketli Topraklar Üzerinde, in his novel titled Gurbet Kuşlarl, it is Istanbul, with its more heterogeneous and cosmopolitan structure, is described as a center in which "encounters" between the peasant and the urbanite intensifies and in which "rarefied and single relations" prevail. In Bereketli Topraklar Üzerinde and Gurbet Kuşları, peasant characters have a sense of both astonishment and timidity when they first see the city.

In his novels, Bereketli Topraklar Üzerinde and Gurbet Kuşları, limbo as a sociocultural concept is reflected through psychological and sociological concepts/traumas created by rural depopulation. In addition, the struggles of peasants who have become alienated from their own culture and compromise/have to compromise their habits and values in forming households in the city, adopting urban practices and being approved by the urbanite constitute are more psychological aspects of migration. In these novels, peasants who are relatively luckier have managed to hold on to the chaos and swallowing nature of the big city and these are individuals who turn their conditions into opportunities thanks to their canny nature.

The places that migrating peasants take shelter in Orhan Kemal's novels are places concretizing rootlessness as well as poverty. These places concretize "social segregation" as well as being against civilized indicators of the urban fabric. One of the indicators concretizing the spatial segregation in the city is slums. Among the greatest dreams of poor workers is the desire to purchase a shanty house and free themselves from the misery of being tenants.

Individuals who migrate from the village to the city have to live in a cultural limbo or conflict due to their differences from the urbanite in terms of both their appearance and behavioral patterns. This limbo occurs first due to their alienation in the city and then due to their alienation from their own "habitus." In Orhan Kemal's novels, the alienation and cultural incompatibilities of individuals who have migrated from the village to the city are bilateral. Individuals who are the actors of migration first see themselves as "others" and form a template and typology of the urbanite. Both in Bereketli Topraklar Üzerinde and Gurbet Kuşlarl, this typology is constantly repeated as a leitmotif: 
Although peasants who have migrated to Istanbul try to adopt urban practices with a permanent settlement, they experience problems of belonging or "yearning for habitus." In Orhan Kemal's novels, the fact that peasants feel alienated, that they are overwhelmed "by the looks of strangers" and that they are alienated/othered by the bourgeois are discussed as reflections of the judgment suggesting that they cannot comply with urban behavioral patterns. In this context, the urbanite tends to stereotype all villagers.

The fact that those migrating from the village to the city speak in a local dialect is disturbing for the urbanite who envisage themselves as an authoritative power and "civilized individuals." The way of speaking and diction are social symbols, which provide tips on the biographical information and cultural identities of individuals, to some extent. On the other hand, the presence of villagers in the city is perceived as a security issue by "owners of the city" and peasants are labeled as criminal individuals threatening order in the city. In this context, every individual migrating from the village is subjected to a categorical attitude by being othered almost as a potential criminal in line with the normative expectations of the urbanite. The fact that the countryman picks up the cost of every adversity in the city is expressed through the urbanite's angry statements.

In this article, the sociocultural effects of migration in Orhan Kemal's novels Bereketli Topraklar Üzerinde and Gurbet Kuşlart are examined through a sociological lens. 


\section{GíRIŞ}

Modern anlamıyla kent, farklı insan topluluklarının bir arada yaşadığı, heterojen özellikler ve ticari/iktisadi örgütlenmelerle ön plana çıkan ve tüketimin hâkim unsur olduğu bir yerleşim merkezidir. "Kentte yaşamak, kente özgü bir hayat tarzını keşfetmek demektir. Her mekân gibi kent de kendine özgü bir hayatı, yaşama üslubunu, ritülleri var eder, bunları yayar” (Alver, 2012, s. 16). Kentin iş imkânı sunmaya ilişkin iktisadi cazibesi, özellikle kırsal kesimlerde geçim derdi yaşayan bireylerin kentleri bir fırsat ve istihdam mekânı olarak görmelerine etki eder. Bauman'ın ifadesiyle kentler, "hazzın ve tehlikenin, firsat ve tehdidin mekânıdır" (2001, s.183). Hem firsatları hem de sosyal ve psikolojik birtakım tehditleri barındıran kentler, pek çok farklı sebebin yanı sıra istihdam imkânı sunmaları nedeniyle de sürekli göçe maruz kalan dinamik yerleşim birimleridir. "Kentlerdeki istihdam firsatı ve yüksek gelir, eğitim, sağl1k ve eğlence gibi imkânlar kırsalda bütün bunlardan yoksun olan bireyleri etkileyerek kentleri çekici kılar. [...] Bireylerin göç kararında, ekonomik gelişmeler ve bu gelişmelerin ortaya çıkardığ 1 fırsatların yanı sıra; eğitim ve sağlık, temiz çevre ve alt yapı yatırımları gibi yaşam kalitelerini ve refah düzeylerini artırıcı unsurlar da etkilidir. Ayrıca kentteki akraba ve tanıdıkların da göç için çekici bir etkisi olduğu söylenebilir” (Kurt, 2018, s. 16). Sosyolojik ve iktisadi pek çok sebebe bağlı olarak ortaya çıkan göç, toplumsal hayatla kuvvetli bir ilişki kuran edebî metinlerde de farklı boyutlarıyla ele alınır.

Temelde sosyolojik bir olgu olarak değerlendirilen göç, son yüzyıllarda yapılan çalışmalarla farklı disiplinlerin de dikkatini çekmeye başlamıştır. Bu bağlamda göçün, hayatla doğrudan bağı olan bir edebî tür olan romana yansıması da hem iktisadi hem sosyolojik hem de psikolojik birtakım verileri içermektedir. Türk edebiyatında özellikle toplumcu gerçekçi romanların yaygınlık kazanmasıyla köyden kente göç olgusu sosyo-kültürel ve sosyo-ekonomik bir sorunsal olarak ele alınmış ve daha çok göçün failleri merkeze alınarak konuya yaklaşılmıştır. Söz konusu romanlarda göç eyleminin faili olan bireylerin, göçe maruz kalan kentlerin insanları tarafından "etiketli/damgalı beden"’ olarak görülmeleri, sosyo-kültürel karşılaşmaların neticesi ve medeniyet söylemiyle kendisini var eden ev sahibi kültürün baskınlığı ile ilgilidir.

\section{1. Üretimin Aktörü Olan İşçilerin Yazgısı: “Göçebe Bedenler"}

Göç, söz konusu eylemi gerçekleştiren bireylerin biyografik bilgilerinde kırılmalara, yenilenmelere ya da sonlanmalara yol açan birtakım sosyo-kültürel ve iktsadi deneyimleri içermektedir. Orhan Kemal'in romanlarında göç, kentlerin sunduğu ekonomik firsatlar nedeniyle pek çok beklentiyi içermekte ve kentler, yoksul bireyleri köyün olumsuz koşullarının yol açtığı

1 Erving Goffman, damgayı itibarsızlaşmış bir sıfata atıfta bulunmak için kullanır ve üç tür damgadan söz eder. "Öncelikle (1) bedenin korkunçlukları-muhtelif fiziki deformasyonları- gelir. Sonra (2) zayıf, irade, baskıya müstehak ya da doğal olmayan tutkular, sapkın ve katı inançlar ve ahlaksızlık olarak algılanan bireysel karakter bozuklukları gelir; bunlar örneğin ruh bozukluğu, hapis yatmak, bağımlılık, alkolizm, eşcinsellik, işsizlik, intihara girişim ve radikal siyasi davranışlar gibi bilindik bir listeden çıkarılır. Son olarak da (3) ırk, ulus ve din gibi etnolojik damgalar vardır; bunlar soy bağıyla aktarılabilir ve eşit bir biçimde bir ailenin tüm mensuplarına bulaşabilir" (2014, s. 33). 
dar çeperlerden kurtaran bir nevi “düş mekânları” olarak yer edinmektedir. Bu bağlamda; "köy yerinde şunun bunun tarlasında üç gün iş, beş gün duvar diplerinde barbut atacaklarına, bir tren parası denkleştirip İstanbul'un yolu tutulmalıydı" (G.K., s.2).

Orhan Kemal'in romanlarındaki köylü karakterlerin kent hayatına ilişkin ilk malumatları, daha önce çalışmaya gidenlerin kente dair olumlu; fakat kentlilere dair olumsuz gözlemlerine/ tecrübelerine ilişkindir. Orhan Kemal'in Bereketli Topraklar Üzerinde ve Gurbet Kuşları romanlarında umuda yolculuğu sağlayan ulaşım araçlarındaki ilk sosyal karşılaşmalar da kentle ilgili tecrübî birtakım bilgilerin paylaşılmasına imkân tanır.

Bereketli Topraklar Üzerinde romanında; iktisadi bir rutin olarak “Orta Anadolu'nun seksen evlik Ç. köyünün erkekleri o yıl da çalışmak için çeşitli iş bölgelerine dağıllırlar]” (s. 1). Bir kısmı, Kayseri Dokuma Fabrikasına, bir kısmı Sivas Çimento Fabrikası Cer Atölyesi'ne gider. Kapı komşusu olan ve çocuklukları bir arada geçen İflahsızın Yusuf, Köse Hasan ve Pehlivan Ali de ekonomik zorunlulukların etkisiyle Çukurova’ya göç ederler. İflahsızın Yusuf, Köse Hasan ve Pehlivan Ali'nin kentsel hayata ilişkin tasavvurları ve hayalleri, diğer mevsimlik işçiler gibi iktisadi hususlarda ortaya çıkar. Zira bu üç arkadaşın da göç etmelerindeki temel sebep de maişet -ekmek derdi- kaynaklıdır. "Toprağın bereketinden umutlanan birey, 'ekmek' uğruna çıktığı yolculukta hep kayıpları yaşar. Emeğin sömürüldüğü, kişisel hakların yok sayıldığı, maddi gücün yok eden bir mekanizmaya dönüştüğü bir zamanda 'bereketli topraklar' kısır ve verimsiz nitelikler kazanır” (Eliuz, 2009, s. 169). Ancak göç, kurak ve verimsiz alanlardan bereketli topraklara yönelmek isteyen bireyler için zaruri bir eylem hâline gelir. Ekonomik sıkışmışlık nedeniyle göç etmek zorunda kalan ve yurtlarından, yuvalarından ayrılan bireylerin temel kaygısı, göçün sebep olduğu koşullara değecek, iyi para kazandıran bir iş bulabilmekir. “ $O$, bu değil ya, gittiğimize göre zorlu bir iş tutaydık bari...” (s.4) ifadeleri, söz konusu kaygıların dillendirilmesidir.

Bereketli Topraklar Üzerinde romanında, göçebeliğin sadece göç eden değil , ötekiler’ yani göçe maruz kalanlar nezdinde de ilk görünürlüğü “yük”lerdir. Nitekim romanın ana karakterleri olan İflahsızın Yusuf, Köse Hasan ve Pehlivan Ali, “omuzlarında beyaz torbaları, koltuklarından birer er kaputu gibi kıvrllıp kınnapla çeke çeke bağll yorganları, tren yoluna in[erler]” (s.1-2). Romanda, göçün kanaatkâr faillerinin genel bir karakteristik olarak beyaz torbaları ve dürülü yorganları ile betimlenmesi, aynı yazgıyı paylaşıyor olmalarının bir göstergesidir. Söz konusu göstergeler, aynı zamanda sefaletin seyyar eşyalar üzerinden somutlanmasıdır. Göçün ortaya çıkardığı yazgı da "gurbet” kelimesinin yüklendiği duygusal anlamla ortaya çıkar. Bu bağlamda Bereketli Topraklar Üzerinde'nin devamı niteliğindeki Gurbet Kuşları romanında, köyden kente göç eden bireyler "gurbet kuşu” metaforu ile kurguya taşınır. Söz konusu romanda "göçebe bedenlerin" gurbette oluşları ya da gurbete gelişleri, yalnızlığa/kimsesizliğe ve yoksulluğa gönderimde bulunan "ne karşılamaya gelenler vardl, ne de çoğunun bavullarlyla sepeti, hatta yorganı." (s.2) ifadeleriyle betimlenir.

Bereketli Topraklar Üzerinde romanında göçe maruz kalan şehir olarak Adana yer alırken Gurbet Kuşlarl'nda ise daha heterojen ve kozmopolit bir yapı gösteren İstanbul, köylü ve 
kentli bedenlerin "karşılaşma” larının yoğunlaştı̆̆ 1 ve "seyreltilmiş, yalınkat ilişkilerin" hüküm sürdügü bir merkez olarak anlatılır. "Göçebe bedenler”in kentli bedenlerle ilk karşılaşmaları da, tedirginlik ve ürkekliğin yanı sıra saf umudu içeren bir duruma karşılık gelmektedir. Söz gelimi; Bereketli Topraklar Üzerinde romanında Çukurova'ya fabrika sahibi hemşehrilerinin yanına gelen İflahsızın Yusuf, Köse Hasan ve Pehlivan Ali, hemşehrilerinin kendilerine sahip çıkacağı umudundadırlar. Oysa fabrika sahibi, arabasından indiği zaman yolunu kesen hemşehrilerine mesafeli davrandığı gibi, "Yıllar yılı vardı memleketten, köyünden ayrılalı. Sonra ne? Ayrılmasa bile doğduğu köye çeşme yaptırmıştı, yol yaptırmıştı, çocuk okutuyordu. Başka ne yapabilirdi?" (s. 47) şeklindeki düşünceleri ile mesafeli tutumunun yol açacağı suçluluk hissini kendince rasyonalize etmeye çalışır. Kapıcısına, hemşehrileri olduğunu söyleyen kişilere uygun bir iş varsa verilmesini söylemesi de baştan savmayı içerir. Hemşehrilik ilişkisinin şehirde anlamsızlaşması ve bir tür duyarsılaşmaya dönüşmesi, İflahsızın Yusuf ve arkadaşlarına işçilerden birinin söylediği "Hemşehrin de olsa ... Şehre göçüp de tüylendi mi, bırak..." (s. 37) şeklindeki ifadelerde anlamını bulur. Öte yandan fabrikada iş bulan arkadaşlardan sulu kozada çalışan Köse Hasan'ın hastalanması üzerine Pehlivan Ali ve İflahsızın Yusuf'un onu kaderine terk ederek eleştirdikleri şehirlilerin mekanikleşen rollerini benimsemeleri de maddi kaygıların yol açtığı bir tutumdur. Kente göç edip uzun süre burada kalanların sonradan gelenlere karşı tavrı da kaba bir tahakkümü ve küçümseyici bir yaklaşımı içerir. Şehre gidenlerin sonradan gelenleri istememeleri ya da görmezden gelmeleri, Gurbet Kuşları'nda tahta bavulu ve yorganı ile İstanbul'daki uzaktan akrabası Gafur'un yanına gelen Memed'in de karşılaştığı bir durumdur. Memed'in umduğu ilgiyi görememesi ve beklentilerinin yerle bir olması, şehirdeki "seyreltilmiş ilişkilerle" ilk yüzleşmesidir. Hamal Veli sayesinde barınma yeri bulan Memed'e buradaki Hacı Emmi'nin söylediği "Hemşeri memşeriye kulak asma," (s. 36) sözü, her iki romandaki karakterlerin de benzer şekillerde deneyimledikleri bir durumu yansitır.

Göçün failleri arasında nispeten şanslı olanlar, büyük şehrin karmaşasına ve yutuculuğuna tutunabilmeyi bir şekilde başarabilmiş ve içinde bulundukları şartları "uyanıklıklarıyla" firsata dönüştürebilmiş bireylerdir. Gurbet Kuşları'nda, çok yoksul bir ailenin çocuğu olarak Anadolu'dan göç eden Hüseyin Korkmaz, bu tiplerin en belirgin örneklerinden biridir. Anasını babasını küçük yaşta kaybeden Hüseyin Korkmaz, dayısıyla birlikte göç ettiği İstanbul'da dayısını da kaybettikten sonra uzun bir süre sefalet içinde hayat mücadelesi verir. Kimsesiz bir göçebe olarak geldiği İstanbul'da hamallıktan müteaahhitliğe/Hüseyin Beyefendiliğe geçen süre zarfında değerlerinden verdiği ödünlerle sınıf atlamayı başarır.

\section{Mekânsal Ötekileşmenin Göstergeleri: Barınaklar, Gecekondular}

Türk kültür ve edebiyatında mekânsal değişimin inşa ettiği yabancılaşma, "gurbet" kavramıyla ifade edilir. Gurbette olmak; "doğup yaşanılmış olan yerden”, aşina olunan ve aidiyet kurulan sosyal çevreden, hayat tarzından uzak olma anlamına gelir. Bereketli Topraklar Üzerinde romanında, ana karakterlerin şehir ve gurbet hakkındaki ilk bilgileri, İflahsızın Yusuf'un emmisinden duyduklarıdır. Yusuf'un emmisinin sözleri, gurbet ile ilgili duygusal ve sosyal tecrübelerin yanı sıra köylülerin kentliler hakkındaki kolektif bilincinin temsilini 
içerir. Gurbete dair ilk bilgiler, emminin ve daha önce birkaç aylığına Sivas'a giden İflahsızın Yusuf'un bireysel tecrübeleri üzerinden kurguya taşınır. Nitekim "gurbete düştünüz mü siz siz olun, sılayı içinizden atın. Atamadınız mı yandınız” (s. 2), "Gurbet gibi kötü var mı? Gavurdan beter dinime imanıma" (s. 3) şeklindeki hükümler, gurbetin duygusal tecrübelerinin oluşturduğu bireysel trajediyi yansıtır. Öte yandan şehrin fiziki yapısının/cazibesinin göz kamaştırıcı etkileri ise "Gece olmaz mi, sokaklarda bütün elektirikler yanar, gündüz gibi, ipil ipil. O tomafiller, o avratlar, o ne bileyim canım, dille tarifi mümkünsüz” (s.6) ifadeleriyle dile getirilir.

Mevsimlik işlerde çalışmak için kente gelen ırgatların kaldıkları yerler, kentsel dokunun medenilik göstergelerine aykırılık özelliği gösterdikleri gibi kent yoksulluğunun ve "sosyal ayrışma”nın da somutlandığı mekânlardır. “Ayrışma, kentlerin sınıf, statü, hiyerarşi, çelişki, eşitsizlik ve bölünme süreçleriyle kuşatıldığına işaret etmektedir” (Alver, 2012, s. 14). Bereketli Topraklar Üzerinde romanında, İflahsızın Yusuf, Köse Hasan ve Pehlivan Ali’nin Çukurova’ya ilk geldiklerinde, sekiz irgatla birlikte eski bir ahırdan bozma, "tabanı hâlâ gübre örtülü" olan ve "ekşi ekşi fişkı kokan" kerpiç bir yerde kalmaları ayrışmanın mekânsal boyutunu yansıtır. İflahsızın Yusuf ve Pehlivan Ali, daha sonra bir inşaatın, karyola olarak kullanılan boş şeker sandıkları, boş çimento torbaları ve kırmızı tuğlalar ile dolu olan "çinko örtmeli tahta barakasında" kalmaya başlar. Hijyenik olmayan bir mekân durumundaki bu köhne baraka, sefaletin yanı sıra yersiz yurtsuzluğun da somut göstergesidir. Benzer bir mekânsal deneyimi, Gurbet Kuşları'nda İstanbul'a giden Memed de yaşar. Hemşehrisi Gafur'a güvenerek İstanbul'a gelen Memed, Gafur'un kendisine yüz vermemesi üzerine Hamal Veli’nin yardımıyla irgatların kaldığı sıvaları dökülmüş, köhne bir konakta kalmaya başlar. "Yıllar yılı çeşitli değişimlerle elden ele geçmiş, elden ele geçerken de hoyratça hirpalanışlarla canlı cenaze hâline gelen” bu konakta "Anadolu'dan İstanbul'a iş için gelmiş, Anadolulu gurbet kuşları" (s. 35) kiracı olarak kalırlar.

Kentteki mekânsal ayrışmayı somutlaştıran göstergelerden birisi de gecekondulardır. Gecekondular, sosyo-ekonomik olarak aynı sınıfa mensup olan ve daha çok köyden kente göç etmiş yoksul bireylerin yuvaya dönüştürdükleri barınma mekânlarıdır. Gurbet Kuşları'nda Memed ve Ayşe, ilk zamanlar, yoksul köylülerin oturduğu bir mahallede, aslında ahır olarak yapılmış, yıllar yılı ahır olarak kullanılmış ve İstanbul'da istimlak başlayıp da yıkım arttıkça, şehirden sürülüp "kendileri gibi, sağda solda çalışan insanlara kiralanmış odaların bulunduğu" (s.349) penceresiz bir yerde kalırlar. Ayşe ve Memed gibi yoksul işçilerin hayallerini, kendilerini kiracılıktan kurtaracak bir gecekondularının olması süsler. Nitekim Memed ve Ayşe, Zeytinburnu'ndan geçen trenlere kuşbakışı bakan bir tepe üzerinde, Ayşe'nin birikmiş paralarını vererek ve geriye kalanı da senede bağlayarak küçücük bir toprak parçası satın alırlar. Romanda Ayşe ve Memed aracılığıyla gecekondu yapma arzusundaki yoksul bireylerin içinde bulundukları durum trajik bir anlatımla kurguya taşınır:

"Daha önce gelmiş, barınaklarının temelini kazan, kazılmış temellere duvarları çıkmaya çalışan ya da sadece briket gibi, tuğla gibi, kum, kireç, çimento gibi yarınki barınaklarının araçlarını bekleyen insanlar; yağmurla, karla, ayazla, çamurla savaşmaya ahdetmiş insanlar.” (s. 353) 
Yoksul bireylerin hayallerini süsleyen gecekonduların yıktırılması ise yersiz yurtsuzlaş(tırıl)manın somutlaştırılmasıdır. "Düşmanları Gafur'un bakışları arasında, Memet'in gecekondularının yıkıntısı yanındaki hâli ve Ayşe'nin düşmanını sevindirmek istemeyen vakur duruşu" (Kurt, 2018, s.213) ve hayata yeniden tutunabileceklerini söylemesi, köylü bedenlerin her şeye rağmen kanaatkâr oluşlarını yansıtmaktadır.

\section{Kültürel Araf/Habitus Çatışması}

Gerek dış görünüşleri, gerek davranış kalıpları bakımından kentli bireylerden farklılık gösteren köylüler, göçle birlikte kültürel bir arafı ya da çatışmayı da yaşamak zorunda kalırlar. Söz konusu araf, öncelikle kentteki yabancılıkla, daha sonra ise kendi "habituslarına"” yabancılaş(tırıl)maları ile ortaya çıkar. Orhan Kemal'in romanlarında köyden kente göç eden bireylerin yabancılaşmaları ve kültürel uyumsuzlukları iki taraflıdır. Göçün faili durumundaki bireyler, öncelikle kendilerini "başka" olarak görüp kentli bireyler hakkında bir tipoloji oluştururlar. Hem Bereketli Topraklar Üzerinde (B. T. Ü.) romanında hem de Gurbet Kuşları'nda (G. K.) bir laytmotif olarak bu tipoloji sürekli tekrarlanır:

“Şehir adamı köylüyü cin çarpar gibi çarpar.” (B.T.Ü., s.2), "Lakin kardaşlar, biz biz olalım, şehirlinin dolabına düşmeyelim. Anam avradım olsun, bizi yek ekmeğe muhtaç ederler!” (B.T.Ü., s.6), "Şehir adamı bir cin” (B.T.Ü., s. 22, G.K, s.6, 258), "Şehirliler beleş beleşine yaralı parmağa işemezler" (B.T.Ü., s. 33), "Emmim derdi ki siz siz olun şehirlinin suyuna göre gidin, şehirli ak derse siz kara demeyin derdi” (B.T.Ü., s. 35), "Şehir adamı yeyime alışkın olur” (B.T.Ü., s. 37), "Siz siz olun şehir uşağına tav olmayın” (B.T.Ü., s.50), "Siz siz olun şehirlinin fendine düşmeyin" (B.T.Ü., s. 53), "Sen sen ol, şehir adamının yanında hımbıl durma derdi" (B.T.Ü., s. 85). "Emmim derdi ki, şehir yerine vardınız mı siz siz olun, şehirlinin ayartmasına kanmayın derdi, şehir uşağı bir cin derdi bir cin” (B.T.Ü., s. 139) "[A]kıl sır ermezdi şu şehir adamlarının işine” (G.K, s.9) "Asbaplı bir cin şeher adamı, köylü kısmını çarpar.” (G.K s.218), "Siz siz olun şeherliye kanmayın!” (G.K, s. 258) "Şeher adamı gözden sürmeyi çeker” (G.K., s.278) "Şehir yerinde hımbı1 olmayacan, delinmedik kabağa girecen!” (G.K., s.19), "Bubam derdi ki, sen sen ol oğlum, şeherlinin dolabına girme, dirdi” (G.K., s.37)

2 Burada Pierre Bourdieu'nun "habitus" kavramına göndermede bulunulmaktadır. "Bourdieu, habitus kavramıla, bireyin kültür ürünleri ve pratiklerine -sanat, yiyecek, tatil, hobi vb- dair beğenisinin geçerliliği konusundaki duygusunu şekillendiren bilinçdışı eğilimlere, sınıflandırma şemalarına, sorgulanmaksızın kabul edilmiş tercihlere gönderme yapar. Burada habitusun yalnızca gündelik bilgiler düzeyinde işlemekle kalmayıp, aynı zamanda bedene kazınmış olduğunun vurgulanması önem taşır. Bedene kazınmış habitus bedenin hacmi, şekli, duruşu, yürüyüş ve oturuş tarzı, yeme ve içme tarzı, bireyin talep etmeye hakkı olduğunu hissettiği toplumsal uzam ve zaman, bedene gösterilen itibar, ses tonu, vurgusu, konuşma örüntülerinin karmaşıklığı, bedensel jestler, bir kimsenin bedeniyle barışıklığı vb'de açığa vurulur. Bunların hepsi bir arada, bir kimseye kökenlerinin kazandırdı ğ alışkanlığı taşır. Kısacası beden, sınıfsal beğeninin maddeleşmesidir: Sınıfsal beğeni vücuda bürünmüştür. Her grup, sınıf ve sınıf fraksiyonu farklı bir habitusa sahiptir" (Featherstone, 2013, s. 161). 
Her iki romanda da; köylü belleğindeki şehirli algısını yansıtan ve sürekli tekrarlanan bu ifadeler, köylülerin şehirlilerle ilgili ilk yargılarını içerir. Şehirliler, duyarsızlıklarının yanı sıra uyanıklıklarıyla da "cin” kavramı ile sembolize edilir. Bereketli Topraklar Üzerinde romanında şehirliler ile kendileri/köylüler arasında bir ayrışma oluşturan ana karakterlerden İflahsızın Yusuf'un "şehirliye hımbıl görünmeyelim" (s. 32) şeklindeki tavsiyesi, öteki olarak kodladıkları şehirlilerin karşısında bilinçli bir kimlik kurgulanmasını içerir. Gurbet Kuşları romanında da benzer ön kabuller ve tanımlamalar, göçün failleri tarafindan sürekli tekrarlanır ve "köylünün kent ve kentliye karşı efsaneye dönüşen kuşkusu bir zihinsel kurulum ya da şablona denk düşer” (Gültekin, 2011, s. 210). Dolayısıyla hem köylü hem de kentli bireyler, birbirlerini öteki şeklinde kodlayarak birbirlerini karşı değer/kültür olarak tanımlarlar.

İstanbul'a göç eden köylü bedenler, daha sonra yerleşik duruma geçerek kentlilik pratiklerini benimsemeye çalışsalar da aidiyet sorunsalı ya da "habitus özlemi” yaşarlar. Bereketli Topraklar Üzerinde romanındaki merkezi karakterlerin hemşehrisi olan fabrika sahibi, onlarla karşılaştığı zaman kentli pratiklerinden sıyrılacağı ve bedenini "habitusun yatkınlıkları[nın]" (Bourdieu, 2015, s. 306) arzuladığı şekilde özgürleştireceği bir çevrede bulunmuş olmayı arzular:

"Onları hemen çevreleyen meraklı kalabalığa karşı piyasasının bozulmasından korkmasa lafı uzatır, yıllardır kendini sıka sıka konuştuğu şehirceden sıyrılır, şunlarla tıpkı onların köycesiyle konuşurdu. Hatta Pehlivan Ali’yle güreşe tutuşabilirdi”’ (s. 47).

Habitusunun yatkınlıklarına göre davranma arzusu, Gurbet Kuşları romanındaki Kabzımal Hüseyin Korkmaz’ın gündelik hayatının neredeyse her anında görülür. Kentli/medeni görünmek adına kendi bireyselliğini yitiren ve karısı Nermin tarafından kendisine iliştirilmeye çalışılan "yamalı pratikler" ile "bedensel ve kültürel yatkınlıkları" arasında bocalayıp duran Kabzımal Hüseyin Korkmaz, karısının sözde seçkinliği üzerinden statü kurgulamaya çalışarak, kent hayatının dayattığı kültürel kalıplara uymakta zorlanır; âdeta arafta kalır. Bu bağlamda o, doğasına aykırı davranmak, "aldatıcı görünüm sergileme[k]" (Goffman, 2014, s. 116) ve kentli imajıyla onaylanmak zorunluluğu neticesinde ne köylü ne de kentli olabilmeyi başarabilir:

\footnotetext{
"Kahverengi İngiliz kupon kumaşından elbisesi içinde Niğde köylerinden birinin her an esneyip gerinmeye can atan, hart hart kaşınmayı, altıkollu iskambil oynamayı, havyarla viski içmeye hemencecik değişivermeye hazır bu, parti ve lüksün bozduğu Anadolulu, hayatından memnun muydu? Mal, mülk, para, kendinden aşağılar yanında önemli kişi sayılmak, şu bu, o rahat rahat esneme, gerinme, hart hart kaşınmaların yerini tutamiyordu" (s. 56).
}

Karısı tarafından kendisine dayatılan ödünç davranışları ve kentli birey rolünü başarısız bir şekilde oynayan, "yamalı bir kimlikle” statü kurgulamaya çalışan Hüseyin Korkmaz, karısı yanında olmadığı zamanlarda rol yapmadan, salt kendisi gibi davranabildiği için “yük”lerinden kurtulmuş gibidir. Kentliler ile arasındaki kültürel mesafeyi aşmaya çalışan ancak arafta kalan köylü öznelerin sembolik bir figürü olan Hüseyin Korkmaz’ın kendi “habitusu”nu oluşturan 
sosyal çevreyi hatırlaması aidiyet sorunsalı ile belirginleşen nostaljik bir özlemi içerir:

\begin{abstract}
"Karısını seviyor muydu, sevmiyor muydu? Seviyordu herhalde ama, ondan ayrıldığı zamanlar dehşetli bir rahatlık, bir ferahlık duyduğu da saklanamayacak kadar açık seçikti. Karısını geceleri yatakta kollarının arasına alsa, ondan sonra bütün gün görmese razıydı. Hatta kolalı yaka, kıravat, İngiliz kupon kumaşından renk renk kostümler, Müetaahhit Hüseyin Korkmaz'lık, karısıyla zaman zaman gittiği Şişli, Nişantaşı sosyetesi, bu sosyetenin süzek bayları bayanları da olmasa, eski komşularının zaman zaman insanı gülmekten kıran şakalaşmalarına kendini bıraksa" (s. 152- 153).
\end{abstract}

Karısı tarafından sürekli bir denetim ve gözetime tabi tutulan Hüseyin Korkmaz'ın, hem bedenine iliştirilen ve üzerinde yama gibi duran kıyafetleri benimseyememesi, hem de içinde bulunduğu sosyal çevreyle aidiyet sorunsalı yaşaması, arafta kalan bireyin gizli huzursuzluğunu içerir. Zira Hüseyin Korkmaz, kendi bireysel kimliği ile karısının ona atfetmeye çalıştığı toplumsal kimliği arasında sürekli bocalayıp durur ve kendi bedenine yabancılaşır. Dış görünüşü ile bireysel gerçekliği arasındaki fark, giyindiği kıyafetler içinde rahat edememesi ve iğreti bir beden olarak görünür olması ile ortaya dökülür:

“Tuttu bana İngiliz kupon kumaşından yallah deyince altı takım elbise yaptırdı. Kemik gibi sert yakalıklar, kıravat, mıravat... Neme gerek benim İngiliz kupon kumaşı, kolalı yaka, kıravat? Biz Anadolu çocuğuyuz arkadaş. Gâvır icadlarının lüzumu yok. Öyle değil mi amma?” (s. 279).

Hüseyin Korkmaz, evde karısı olmadığı zamanlarda, habitusunun, "bedene işlemiş yatkınlıklarının" (Bourdieu, 2015), gerektirdiği gibi davranarak karısının yasakladığı beyaz gecelik entarisini giyinir, yere serili sofra bezinin kenarına bağdaş kurar. Zira beden, "sınıf beğenisinin farklı şekillerde dışa vurulan en reddedilemez nesneleşmesidir” (Bourdieu, 2015, s. 281). Bu bağlamda İflahsızın Yusuf'un odasında hizmetçi Ayşe’ye yer sofrası hazırlattırması da köylü sınıfın “yaşam stili” olarak kurguya yansır. Öte yandan Hüseyin Korkmaz’ın; “[ ...] memleketimdeki dere boyunu, dere boyunun ceviz gölgesini versinler, İstanbulları da, bu köşk de, kabzımallık da kendilerinin olsun!" (s. 276) şeklindeki ifadeleri de "yamalı kimlik”le görünür olmanın yol açtığı huzursuzluğu yansıtmaktadır. Kabzımal Hüseyin'in köy pratiklerinden vazgeçmemesi, İflahsızın Yusuf ile doğal bir samimiyet kurmalarında da etkili olur. İflahsızın Yusuf'un; "Hanıma kulağasma ya, seni pek sevdim bey. Neden dirsen şahar adamına benzemen!" (s. 275) şeklindeki sözleri, habitus benzerliğinin inşa ettiği kültürel yakınlığa işaret eder.

Kent hayatının sosyal rollerde de çatışma oluşturması ve değerler dizgesinin değişmesi, 'gurbet kuşları'ndan Memed'in babasına karşı tavrında açıkça görülür. Geleneksel hayat tarzında toplumsal bir değer olarak kutsanan "babaya koşulsuz itaat”, kentte artık yerinden edilen ve geçerliliğini yitiren bir değer olarak karşımıza çıkar. Ancak itaatsizliğin altında yatan temel gerçeklik ise kent hayatının öğretmiş olduğu bireysellik ve başkasına bağımlı olmadan kendini gerçekleştirebilme edimidir. Öte yandan kent hayatını deneyimleyenlerin ve 
kentlilik pratiklerini benimsemiş görünenlerin köylerine döndükten sonraki tutumlarında yer yer "üstünlük kompleksi" ve kendilerini ayrıcalıklı hissettirme çabaları sezilir. Söz gelimi; Bereketli Topraklar Üzerinde romanında Çukurova'ya giden Pehlivan Ali, köyüne döndüğünde köylülerini imrendirecek bir şekilde Çukurova'yı anlatmanın ve onlara "siz bilmezsiniz" demenin hayallerini kurar. Gurbet Kuşları'nda da bütün imkânlarını seferber ederek İstanbul'a gidenler ve aslında orada sefil bir hayat sürenler "birkaç ay sonra değişmiş dön[erler]" (s. 2). "Taralı saçları, kopçalı sarı kalemleri, karton kaplı cep defterleri, arkaları çıplak kadınlı cep aynaları, Tahtakale'den uydurulmuş üst başlarıla köy yerinde dolanı[rlar], köy kahvelerinde, delikanlı meclislerinde İstanbul'u dillerinden düşürm[ezler]" (s. 2). İstanbul'da uzun y1llardır kalan Gafur'un köyünü ziyareti de böyle bir farklılığı içermektedir. "Şehirli biçimi siyah paltosu, mavi pantolonu, sarı kunduruları, sarı ă̆ızlı̆̆l, kutu kutu şehir sigaraları”, "lenger şapkası, sarı atkısı, sarı tară̆ı, koçalı sarı kopya kalemi" (s. 4) ile köye "kurula kurula" mağrur bir edayla gelen Gafur, hem dış görünüşü hem de üstünlük içeren davranışlarıyla kendisini doğup büyüdüğü toprağın insanlarından ayrıştırır. Uzaktan akrabası Memed yanına geldiği zaman söylediği; “Ístanbul'un daşı toprağı altın belliyorlar. Dilenci doldu İstanbul'un sokakları meydanları tüm!’ (s.43) şeklindeki sözleri, şehri sahiplenmeye ve kendi geçmişini yok saymaya ilişkin bir kompleksi içerir.

İstanbul'a çalışmaya giden Memed de, şehre adımını attıktan kısa bir süre sonra, köye döndüğünde bir rol model/idol olarak belirlediği Gafur gibi davranmanın hayallerini kurar. Zira köy yerinde âdeta “bir masal/düş mekânı” olarak tasavvur edilen İstanbul'u görmüş olmanın bile kendisine bir ayrıcalık/itibar ihdas edeceği düşüncesini taşır. "Kahvede Ístanbul'u anlatırken herkes Gafur Ağasını dinler gibi dinleyecek şaşacaklardı. Şehir biçimi siyah bir palto, sarı boyun atkısı, sarı kunduralar, kopçalı sarı kalem, gümüş ăgılık” (s. 6) ile köylülerinde hayranlık oluşturacaktır. "Dolayısıyla şehir bunca kötülüğü ve hainliği barındırmasına karşın

gizli bir hayranlığı da beslemektedir. Köylünün ikircikli davranışının temelinde bu hayranlık hissi vardır biraz" (Alver, 2014, s. 249). Bu bağlamda Memed'in şehir görmüş olmaya dayalı bir saygınlık, güç ve sosyal doyum inşa etmek istemesi, her iki romanda da şehir gören karakterlerin ötekine dönüşmeyi içten içe arzuladıklarını yansıtır.

\section{Bedene/İfadeye Yansıyan Farklılık}

Köy ve kent arasındaki farklılıklardan birisi, her iki yerleşim biriminde toplumsal düzeni inşa eden hayat tarzının ve kültürel kalıpların insanı biçimlendirme bağlamında farklı özellikleri ihtiva etmesidir. Dolayısıyla köylü bedenlerin kentte, kentli bedenlerin köyde "tekinsiz", "güvensiz" olarak algılanmaları ve zaman zaman dışlanma içeren muamelelere maruz kalmaları, sonradan katıldıkları bir sosyal çevredeki insicamı bozuyor olduklarına ilişkin birtakım ön kabullerin ve davranış kurallarına riayet etmediklerine dair bir algının sonucudur. Orhan Kemal'in romanlarında köylü bedenlerin kentte "yabancılık" çekmeleri, "yadırgı bakışların ă̆ırlı̆̆ı" altında ezilmeleri ve kentsoylular tarafından yabancılaştırılmaları/ötekileştirilmeleri de böyle bir ön kabulün ve kente ait davranış kalıplarına riayet edemediklerine ilişkin yargıların yansıması olarak ele alınır. Bu bağlamda kent sakinleri, bütün köylüleri stereotipleştirme eğiliminde olurlar. 
"Stereotipler toplumsal, ekonomik, kültürel anlamda çatışmanın, 'bizden'liğin, ötekileştirmenin, kendinden saymamanın, kendisini konumlandırmanın ve yakınlık/uzaklık algısının yok saymanın, yadsımanın, yüceltmenin, olumlamanın, olumsuzlamanın, yargılamanın, değer yargılarının, görüş ayrılıklarının, kısacası, hayata bakışın, toplumsal yaşamı ve dünyayı algılayışın ve anlamlandırışın bir sonucu olarak ortaya çıkar ve varlığını devam ettirir” (Demir, 2014, s. 12). Orhan Kemal'in Bereketli Topraklar Üzerinde ve Gurbet Kuşları romanlarında olumsuz içeriklerle donatılmış stereotipler, baskın bir şekilde görülmektedir. Ancak kentlilerin köylülere ilişkin oluşturdukları stereotiplerde aşağılayıcı ifadeler daha yoğundur.

Köylü bedenlerin kentli bedenlerden ayrıştığ 1 ve "uyumsuz bedenler" olarak etiketlendiği ilk belirleyiciler arasında kılık- kıyafet ve davranışsal farlılıklar yer alır. Dolayısıyla "kıyafetler üzerinden aktarılan toplumsal bilgi” (Goffman, 2014, s. 85) gayrimedeni olarak kodlanan köylülerin "aşağılanmasına ve özellikle kamusal alanda kabul görmemelerine ve "düşmanca bir kamusal ilgi[ye]” (Goffman, 2014, s. 113) maruz kalmalarına yol açmaktadır. Zira "kent yaşamında "benliğin sunumu" birincil olarak ve her şeyden önce, belki de sadece yüzeylerin sunumudur" (Bauman, 2001, s. 180). Özellikle kıyafetlerin temsil ettiği kentlilik ya da medenilik, hem Bereketli Topraklar Üzerinde' de hem de Gurbet Kuşları'nda köylü bedenlerin kamusal alanda doğrudan ayrıştırılmasına yol açmaktadır. Bu bağlamda Orhan Kemal'in romanlarında, fiziksel olarak yakın ancak sınırları pek de kolay kapanmayacak bir şekilde toplumsal açıdan uzak olan köylüler ve kentliler arasındaki yabancılık, dış görünüşteki farklılıkla belirginleşen zihinsel ve kültürel bir mesafeyi içermektedir. Böyle bir mesafe, özellikle kentin yerli sakinlerinin köylüleri “dışlama ve sınıflama üzerine dayalı” (Sakız, 2019, s. 4) ayıplamaları, kınamaları ve azarlamalarıyla gerilimli bir ilişkiye dönüşür.

Sosyo-ekonomik eşitsizliğin beden üzerinden "toplumsal bilgi” hâline gelmesi ve kılık kıyafetin "statü sembolü" olarak algılanması, Bereketli Topraklar Üzerinde romanındaki ana karakterlerin trende karşılaştıkları Sivas'ın köylülerinden olan Veli’nin kılık kıyafetiyle üstünlük inşa etme çabasında görülür. Üstü başı düzgünce olan, bacağında dokuma bir külot pantolon, sırtında lacivert yün kumaştan bol ceket, ceketinin mendil cebinde kopçalı, sarı bir kurşunkalem bulunan Veli’nin kendisini ayrıcalıklı bir köylü olarak göstermesi, öncelikle kılık kıyafetiyle ortaya çıkar. Nitekim yün ceketinin altındaki beyaz gömleğini göstererek, ağasının gömleği olmasıyla övünen Veli, "Efendi gömleği” diyerek kendince bir statü sınırı ihdas eder.

Bedensel görünüş ve davranışlarla ortaya çıkan farklılık, Gurbet Kuşları romanında özellikle Kabzımal Hüseyin Korkmaz ve karısı arasında görülür. Kabzımal Hüseyin'in karısı Nermin, babası doktor olan, İngilizce, Fransızca ve Rumca bilen birisi olarak kentli elit tabakanın temsilcilerinden birisidir. Kentli ve seçkin olmanın ayrıcalığını sadece çevresindekilere değil köylü pratiklerini bir türlü terk edemeyen ve "çarıklı" diye hitap ettiği kocasına da sürekli hissettiren ve milletvekili olması için uğraştığı kocasını "yontma” mücadelesi veren Nermin'in siyasi atmosferde sağladığı güç aslında tamamen kadınlığı dolayımındadır.

Orhan Kemal'in romanlarında köyden göç edenlerin yöresel ağızla konuşmaları da kendilerini 
otoriter bir güç/ses ve "medeni bireyler" olarak tasavvur eden kentlileri rahatsız eden bir durumdur. Konuşma şekli ve diksiyon, bireylerin biyografik bilgisi ve kültürel kimlikleri hakkında kısmi de olsa ipuçları sunma özelliğini barındıran toplumsal sembollerdir. Gurbet Kuşları'nda Çırçır fabrikası kâtibinin “donuyoruz” demeye dili dönmediğini söyleyerek ısrarla "donuyok" demeye devam eden ırgatı azarlaması üzerine irgatbaşının, "nefesini tüketme. Bunlar nerde insanlık nerde. Bunlara var mı somun! Yerler! Var mı nallı Fatma? Tamam..." (s. 62) ifadeleriyle ona destek çıkması, konuşma dili üzerinden de sosyal bir hiyerarşi oluşturulduğunu ortaya koyar. Oysa 1rgat, bilinçli bir şekilde "donuyok" demesinin gerekçesini "bizi ayı kendisini adam bellesin fikara!” şeklinde açıklayarak söz konusu ayrıştırmanın yüzeyselliğinin farkındalığını yansıtır.

Köylü bireylerin kentin “saf”lığını bozduklarına ilişkin benzer bir yaklaşım, Gurbet Kuşları'nda vapurdaki biletçinin, İflahsızın Memed'e karşı tavrında da görülür. Bavuluna bilet alıp almadığını soran biletçiye Memed'in ,"virmediler" demesi üzerine biletçinin genç adamı; "Pis şivesi bozuk" (s. 16) şeklinde azarlaması, romanın canlı karakterlerinden birisi olan Kabzımal Hüseyin Korkmaz’ın gündelik hayatının bir rutinidir. Karısı Nermin tarafından konuşması sürekli düzeltilen Hüseyin Korkmaz, karısı yanında olmadığı zamanlarda da şiveli konuştuğunda bir tedirginlik hisseder. Oysa karısının kendisini sürekli düzeltmesinden rahatsızdır: "Bana sorup danışmaz, beni koca yerine komaz. Sonra bir de dil meselesi. İnsan olan bir insan anasının babasının konuştuğu dilinen konuşur.” (s. 278).

Köylü bedenlerin, kent hayatının akışında olumsuz içeriklerle donatılmış bir "kamusal ilgi”ye maruz kalmaları, özellikle Gurbet Kuşları romanında küçümseyici ön kabuller üzerinden yansitılır. "Çevrelerine yenik, şaşkın, mahcup, korkak bakışları, yeşil, sarı, mor, kırmızıları kirli çorapları, kirli tırnaklarıyla etlerini hart hart kaşıyışlarıyla" (s.2) betimlenen "gurbet kuşları"nı hakir gören ya da alaya alan kentlilerin kalıplaşmış tepkileri ve köylüleri itibarsızlaştırmaya ilişkin ritüelleşmiş davranışları, "ayı”, "sürü", "hayvan”, "yarma”, "yabani”, "çarıklı” gibi hakaretamiz sözcüklerle sembolize edilen dilsel tahakkümde belirir. Kendilerini kentin sahibi ve medeni sakinleri olarak görenlerin, "köylü bedenleri” aşağılama sebeplerinden birisi de yabanc1lar/turistler nezdinde küçük düşme korkusudur. Nitekim "bu sefaletlerini köylerinde saklayıp da İstanbul'da yabancılara teşhir etmeseler olmaz mı?” (s. 3) "Çarşıda bunlar, pazarda bunlar, Beyoğlu'nda bunlar be ! Insan turistlerden utanıyor!” (s. 186) ifadeleri, bir tür aşağılık kompleksinin yansımasıdır. Öte yandan kent hayatı içerisinde, toplumsal hiyerarşi tarafından belirlenen meşruiyet sorunu ile yüzleşmek zorunda kalan ve "karşı değer" ya da "uyumsuz bedenler" olarak etiketlenen köylülerin trenden, vapurdan suçlu suçlu inmeleri ve "fötr şapkaları, terli bıyıkları kaşlarılla [kendilerine] ters ters bakanlar[a]" (s. 7) ne tepki vereceklerini bilememeleri, ötekileştirilmelerinin birer göstergesidir.

Gurbet Kuşları'nda sosyal bariyerlerle karşılaşan köylü bedenler, "pis pis kokuyor lanet" (s.7) “Istanbul bunlarla dolu” (s. 7), “ormanın yakanın gözü kör olsun” (s.11) "başlarım şimdi ormanını yakandan ha" (s. 184), gibi sözlere maruz kalmalarının yanı sıra kentlilerin dışlama pratiklerine de muhatap olurlar. Zira sadece kendilerini "kamusal bedenler" olarak gören kentli 
bireyler, köylü gördükleri bireylerle "tüm bilinçli temaslardan ve en önemlisi on[ların] bilinçli bir temas olarak görebileceği davranışlardan gayretle kaçınılan” (Bauman, 2001, s. 189) bir tutum sergilerler. Kentlilerin tahkir içeren davranışlarının yanı sıra sözde merhametlerinde de bir aşağılama söz konusudur. İstanbul'a ilk geldiği anlarda vapurda yanlış yere oturan Memed'in biletçiyle yaşadığı iletişim sorununa çevredeki kadınların bir kısmı acıyarak bakarlar. Ancak kentli bedenlerden birisinin "zavallı" demesi üzerine etraftan "zavallı ha? Zavall o değil bizleriz, şehirliler! Bunca yıllık tahsilimize, şehirliliğimize rağmen, ikinci biletiyle birincide seyahat etmeyi düşünemeyiz!” (s. 15), "tenezzül etmeyiz deyin şuna. Ama onlar, şu ayılar var ya, şu ayılar! Her şeye tenezzül ederler. Sorarım size apartman kapıcıları bunlardan başkası $m ı$ ?" (s. 15) şeklinde cevaplar verilmesi, basit bir yanlış yere oturma olayının "uyanık”lı̆ga ve "kurnazlığa" bağlanmasını yansitır.

Gurbet Kuşları'nda kendilerini muktedir bir güç olarak gören kentli bireylerin köylüleri ötekileştirmeleri, kentliliğe ilişkin üstünlük kompleksini yansıtan kolektif algının açığa vurulmasıyla ortaya çıkar. Köylü bedenler, kentin medeni dokusuna "leke" süren ve “atık”laştırılması ${ }^{3}$ ya da uzaklaştırılması gereken yabancılar olarak değerlendirilir. Köylü ve kentli bedenlerin sosyal karşılaşmaları da özellikle kendilerini yerli sakinler olarak gören kentliler tarafından oluşturulan gerilimli bir atmosferi haizdir. Söz konusu durum, "yabancı”laştırma eğiliminin bir neticesidir. Aynı inşaatta çalıştığı arkadaşı Kastamonulu ile birlikte Tarlabaşı asfaltı üzerinde küçük bir çay ocağına giden Memed'in kılık kıyafetinden dolayı alay edilerek sindirilmeye çalışılması, bir sosyalleşme mekânı olan ve daha çok halktan insanların bir arada bulunduğu kahvehanenin sınıfsal bir ayrışma alanına dönüşmesini yansıtır:

“Büyük şehir insanının huyuydu bu. Köyünü, kentini bırakıp büyük şehre ekmek için düşmüş yaban bakışlı, bozuk üst başlı, şivesi bozuklarla alay ederler, onları büyük şehre yakışmayan taraflarından dolayı tefe alırlardı” (G. K., s. 184)

Köylü bedenlerin kente göç etmeleri, kentin arınık dokusunu bozan bir husus olarak görüldüğü gibi sınırları kentliler tarafından çizilen simgesel mesafeler, iki taraf arasındaki sosyal gerilimin de derinleşmesine yol açar. Bauman'a göre; “[...] tüm zaman ve mekânın yerlileri, yabancıları ayırma, dışlama, sürme ve yok etme yönündeki çılgın çabalarında hedeflerini haşerat ve bakterilere benzetirler. Yine, bunlar kendi hareketlerinin anlamını hijyenik rutinlere benzetirler ve yabancılarla, hastalık taşıyıcılarına karşı sağlığı savunan kişiler olarak savaşırlar” (2013, s. 21). Bu tür bir yaklaşım, Gurbet Kuşları romanındaki kentli bireylerin de davranışlarında görülür:

"Ne diye köyünde tarlasıyla uğraşmaz da gelir İstanbul'u kirletirler? İstanbul sokakları bunlardan, bunların sefaletinden geçilmiyor! [...] Hükümetin yerinde ben olacağım ki bak... Ver nüfus kâğıdını. Nerelisin? Erzurumlu, Vanlı, Bitlisli, Adanalı... Marş

3 Zygmunt Bauman'a göre "İnsan birlikteliği biçimlerinin tasarlanmasında atık, insandır. Tasarımın formatına uymayan, uydurulamayan kimi insanlardır. Ya da tasarımın saflığını bozan, saydamlığını gölgeleyenlerdir[...]” (2018: 44). 
geldiğin yere. İstanbul İstanbulluktan çıktı be!" (s. 185-186).

"İnsan yurttaşım, vatandaşım demeye utanıyor. Bunlar adam olacak da, vatana, millete, memlekete fayda sağlayacak. Ölme eşeğim ölme...” (s. 186).

Köylülerin kentte bulunmaları "kentin sahipleri” tarafından bir asayiş meselesi olarak algılandığ 1 gibi köylüler, kentsel düzeni tehdit eden kriminal bireyler olarak etiketlenir. $\mathrm{Bu}$ çerçevede köyden göç eden her birey, kentlilerin normatif beklentileri doğrultusunda âdeta potansiyel bir suçlu olarak ötekileştirilerek kategorik bir tutuma maruz kalır. Kentteki her olumsuzluğun faturasının köylülere çıkarılması da mütehakkim tavırlarla belirginleşen öfke söylemleriyle açı̆̆a vurulur:

“Tavla, iskambiller bırakılmıştı. Ayağının çarı̆̆ıyla gelip İstanbul'da yosun tutanlar üzerine bol bol örnekler verilerek konuşuluyordu. Konu yavaş yavaş karaborsaya, ahlakın bozuluşuna geldi. Bütün bunlar hep taşradan kalkıp kalkıp buraya gelen, burada dişinden tırnağından artırıp üç beş kuruş biriktirdikten sonra parasını faize veren, faizin faizi, derken karaborsa, talan, hırsızlıkla zenginleşenler yüzündendi” (s. 188).

Haydarpaşa Garı; “yorganlı yorgansız, bohçalı, bohçasız” köylü bedenlerin toplu olarak görüldükleri ve köylülerle kentliler arasındaki sembolik sınırın ilk aşıldığı/ihlal edildiği mekân olduğu için Gurbet Kuşları'nda köylü ile kentli karşılaşmasının en belirgin yaşandığı yer olarak kurguya dâhil edilir. İflahsızın Memed'in İstanbul'a ilk geldiğinde yaşadığı “gerilimli karşılaşmalar”, babası ve kardeşleri Haydarpaşa Garı'nda trenden indikleri anda da deneyimlenir. Köylülerin kılık kıyafetlerinden ve davranışlarından dolayı "ayılara hele ayılara!' (s.3, s.140, s. 261), "Şerefsizim sürü!’”(s.3, 261), "Her gün bu, her gün bu. Köylerinden ne diye ürkütürler bu hayvanları bilmem ki?” (s. 3) şeklinde tahkirlere maruz kalmaları, aynı mekân üzerindeki eşitsizliğe gönderimde bulunmaktadır. Ancak Memed'in, bir zamanlar Kastamonulu'nun kahvedeki kentlilere söylediklerini hınçla tekrarlayarak kentli bilince karşı bir direniş geliştirmesi, kentliler ile arasındaki mesafeyi yok saymaya ilişkin bir tutumdur.

\section{SONUÇ}

Göç olgusu, hem yerel hem de küresel bağlamda yerlilerin göç edenleri kabullenmekte zorluk çektikleri ve genel bir karakteristik olarak göçün faillerinin toplumsal onay alamadıkları bir duruma karşılık gelir. Türk edebiyatında göçün ele alınma biçimi genel bir temayül olarak üç şekildedir: Köyden kente göç, başka bir ülkeye göç ve Balkanlardan Türkiye’ye göç. Söz konusu göçlerin yansıtılmasında kültürel karşılaşmaların yol açtığı sosyal çatışmalar, "kültürel araf" ve "habitus çatışması" bağlamında kurguya taşınır. Özellikle toplumcu gerçekçi bir tavırla eserler kaleme alan yazarların romanlarında göç, ekonomik imkânsızlıklardan kurtulmak isteyen köylü bireyler için bir çıkış yolu olarak kurguya taşınır. Orhan Kemal'in romanlarında da göç olayı, köyün iktisadi sınırlılığından kurtulmak isteyen bireyler için bir umut yolculuğudur. Özellikle Bereketli Topraklar Üzerinde ve Gurbet Kuşları romanlarında, göç olgusu sosyokültürel ve sosyo-ekonomik açıdan kurgusallaştırılır. 
Hem Bereketli Topraklar Üzerinde hem de Gurbet Kuşları romanında, kanaatkâr köylülerin kente göç ettikten sonra yaşadıkları toplumsal çatışmalar ve yabancılaşma, kültürel araf bağlamında sunulur. Söz konusu kültürel araf, kent atmosferinin sebep olduğu yabancılığın bir süre sonra kendi kültürüne yabancılaşmaya dönüşmesi ile sonuçlanır. Öte yandan kentli olmak ya da en azından kenti görmüş olmak bile bir statü kazanımı olarak algılanır. Orhan Kemal'in romanlarında köylüler, kentliler ile ilgili olumsuz düşünceler besledikleri gibi kentliler de köylüleri ötekileştirme eğilimi içerisinde olurlar. Kentlilerin, köylülere karşı davranışları köylüleri dışlamaya, aşağılamaya ve etiketlemeye ilişkin âdeta reflekse dönüşen pratikleri içerir.

Hakem Değerlendirmesi: Dış bağımsız.

Çıkar Çatışması: Yazar çıkar çatışması bildirmemiştir.

Finansal Destek: Yazar bu çalışma için finansal destek almadı̆̆ını beyan etmiştir.

Peer-review: Externally peer-reviewed.

Conflict of Interest: The author has no conflict of interest to declare.

Grant Support: The author declared that this study has received no financial support.

\section{KAYNAKÇA/REFERENCES}

Alver, K. (2012). Kent imgesi. K. Alver (Ed.), Kent sosyolojisi içinde (s.9-33). Ankara: Hece Yayınları. Alver, K. (2014). Bereketli topraklar üzerinde. Hece Dergisi, (18) 205, 246- 254.

Bauman, Z. (2001). Parçalanmış hayat (İ. Türkmen, Çev.). İstanbul: Ayrıntı Yayınları.

Bauman, Z. (2013). Postmodernizm ve hoşnutsuzlukları (İ. Türkmen, Çev.). İstanbul: Ayrıntı Yayınları.

Bauman, Z. (2018). Iskarta hayatlar (O. Yener, Çev.). İstanbul: Ayrıntı Yayınları.

Bourdieu, P. (2015). Ayrım (D. F. Şannan, A. G. Berkkurt, Çev.). İstanbul: Heretik Yayınları.

Demir, A. (2014). Roman ve stereotip (1.bs). İstanbul: Nobel Yayınları.

Eliuz, Ü. (2009). Orhan Kemal ve romancılığı (1.bs). Ankara: Millî Eğitim Bakanlığı Yayınları.

Featherstone, M. (2013). Postmodernizm ve tüketim kültürü (M.Küçük, Çev.). İstanbul: Ayrıntı Yayınları.

Gültekin, M. N. (2011). Orhan Kemal'in romanlarında modernleşme, birey ve gündelik hayat (1. bs.). İstanbul: Everest Yayınlar1.

Goffman, E. (2014). Damga örselenmiş kimliğin idare edilişi üzerine notlar (Ş. Geniş, L. Ünsaldı, S. N. Ağırnaslı, Çev.). Ankara: Heretik Yayınları.

Kurt, A. (2018). Memleketi İstanbul'a taşımak 1950 sonrası Türk romanında göç. (1. bs.). İstanbul: Akademik Kitaplar.

Orhan Kemal (2013). Bereketli topraklar üzerinde (27. bs). İstanbul: Everest Yayınları.

Orhan Kemal (2015). Gurbet kuşlarl (11. bs). İstanbul: Everest Yayınları.

Sakız, Halis (2019). Kapsayıcılık paradigması çerçevesinde göçmen bireyler, H. Sakız, H. Apak. (Ed.), Türkiye'de göçmen kapsayıcılı̆̆ı içinde (s.1-14). İstanbul: Pegem Yayınları. 